\title{
Metabolic effects of activation of CCK receptor signaling pathways by twice-daily administration of the enzyme-resistant CCK-8 analog, (pGlu-GIn)-CCK-8, in normal mice
}

\author{
Nigel Irwin, Pamela Frizelle, Finbarr P M O’Harte and Peter R Flatt \\ School of Biomedical Sciences, The SAAD Centre for Pharmacy and Diabetes, University of Ulster, Coleraine, \\ Northern Ireland, UK
}

Correspondence should be addressed to $\mathrm{N}$ Irwin

Email

n.irwin@ulster.ac.uk

\begin{abstract}
Cholecystokinin (CCK) is a hormone that has important physiological effects on energy balance. This study has used a stable $\mathrm{CCK}_{1}$ receptor agonist, (pGlu-GIn)-CCK-8, to evaluate the metabolic effects of prolonged administration in normal mice. Twice-daily injection of (pGlu-GIn)-CCK-8 for 28 days resulted in significantly lowered body weights $(P<0.05)$ on days 24 and 28, which was associated with decreased accumulated calorie intake $(P<0.01)$ from day 12 onward. Nonfasting plasma glucose was significantly reduced $(P<0.05)$ on day 28 , while plasma insulin concentrations were increased $(P<0.05)$. After 28 days, glucose tolerance and glucose-mediated insulin secretion were not significantly different in (pGlu-GIn)-CCK-8-treated mice. However, following a 15-min refeeding period in 18-h fasted mice, glucose levels were significantly $(P<0.05)$ decreased by (pGlu-GIn)-CCK-8 despite similar food intake and nutrient-induced insulin levels. Insulin sensitivity in (pGlu-GIn)CCK-8-treated mice was significantly $(P<0.01)$ improved compared with controls.

Accumulation of triacylglycerol in liver was reduced $(P<0.01)$ but there were no differences in circulating cholesterol and triacylglycerol concentrations, as well as triacylglycerol content of pancreatic, muscle, and adipose tissue in (pGlu-Gln)-CCK-8 mice. These data highlight the beneficial metabolic effects of prolonged (pGlu-GIn)-CCK-8 administration and confirm a lack of detrimental effects.
\end{abstract}

\author{
Key Words \\ - cholecystokinin (CCK) \\ - glucose homeostasis \\ - insulin sensitivity \\ - food intake
}

Journal of Endocrinology (2013) 216, 53-59

\section{Introduction}

Cholecystokinin (CCK) is considered to be an important hormone in terms of biological effects on food intake and overall energy balance (Rehfeld 2011). CCK was first isolated from porcine duodenal mucosa as a 33 amino acid intestinal hormone (Mutt \& Jorpes 1968) that was shown to release pancreatic amylase and other enzymes
(Mutt 1980). However, CCK is now known to exist in a number of molecular isoforms, of which the C-terminal octapeptide (CCK-8) represents the most abundant molecular species and importantly retains full biological activity (Rehfeld et al. 2007). Moreover, CCK is now mainly recognized through its ability to stimulate 
short-term satiety by activation of $\mathrm{CCK}_{1}$ receptors in vagal afferent neurons (Strader \& Woods 2005). However, in addition to this, CCK also plays a significant role in a number of other important physiological processes including insulin secretion, gastric emptying, and bowel motility (Liddle 1994). More recent evidence reveals that CCK acts as a growth factor and anti-apoptotic agent for pancreatic $\beta$-cells (Kuntz et al. 2004, Chen et al. 2007). In agreement, dual elimination of receptors for glucagon and the incretin hormone, glucagon-like peptide-1, clearly show the importance of CCK receptor signaling in the regulation of insulin secretion and glucose homeostasis (Ali et al. 2011).

Studies in CCK receptor-deficient rodents shed further light on the important physiological role of CCK. Thus, Otsuka Long Evans Tokushima Fatty (OLEFT) rats, which have a $6847 \mathrm{bp}$ deletion within the gene for the $\mathrm{CCK}_{1}$ receptor protein resulting in disrupted $\mathrm{CCK}_{1}$ receptor production, present with hyperglycemia, hyperphagia, impaired glucose tolerance, and mild obesity (Moran 2008). Interestingly, in mice with genetic deletion of the $\mathrm{CCK}_{1}$ receptor, the adverse effects are much less obvious (Bi et al. 2007). However, an inherent problem with models such as this is the lifetime opportunity for compensatory metabolic adaptation. Nevertheless, administration of $\mathrm{CCK}_{1}$ receptor antagonists results in increased meal size and overall food intake (Moran et al. 1993), while administration of native CCK reduces food intake and results in early satiety in rodents and humans (Gibbs et al. 1973, Degen et al. 2001). In addition, in patients with bulimia, there is an impaired secretion of CCK in response to a meal (Devlin et al. 1997).

Thus, taken together, $\mathrm{CCK}_{1}$ receptor activation possesses biological characteristics that would suggest potential therapeutic application for obesity and related metabolic disturbances. As such, numerous studies have shown notable therapeutic effectiveness of longer-acting CCK-based compounds (O'Harte et al. 1998, Verbaeys et al. 2007, 2008, 2009a). In particular, the recently characterized N-terminally modified, enzymatically stable CCK-8 analog, (pGlu-Gln)-CCK-8, causes sustained weight loss and improves both insulin resistance and glucose tolerance in mice with genetically and environmentally induced forms of obesity-diabetes (Irwin et al. 2012). Therefore, in this study, (pGlu-Gln)-CCK- 8 has been used to evaluate the effects of short-term upregulation of CCK receptor signaling on energy intake, body weight regulation, glucose homeostasis, insulin secretion and sensitivity in normal mice. In view of the possible therapeutic application and increasing awareness of the metabolic role of CCK-8, evaluation of the effects of extended (pGlu-Gln)-CCK-8 action under normal physiological conditions is of value. This study indicates that (pGlu-Gln)-CCK-8 exerts beneficial effects on body weight regulation and insulin sensitivity with no obvious signs of malaise or harmful effects on behavior.

\section{Materials and methods}

\section{Peptides synthesis}

(pGlu-Gln)-CCK-8 was obtained from American Peptide Company (Sunnyvale, CA, USA) and characterized using matrix-assisted laser desorption ionization time-of-flight (MALDI-TOF) mass spectrometry (Kerr et al. 2009).

\section{Subchronic metabolic effects in normal mice}

Over a 28-day period, 14- to 16-week-old male Swiss NIH mice $(n=8)$ maintained on a standard rodent maintenance diet (10\% fat, $30 \%$ protein, and $60 \%$ carbohydrate, Trouw Nutrition, Cheshire, UK) on reversed light cycle (lights off between 0930 and $2130 \mathrm{~h}$ ) received twice-daily i.p. injections (0900 and $1700 \mathrm{~h}$ ) of either saline vehicle $(0.9 \%(\mathrm{w} / \mathrm{v}), \mathrm{NaCl})$ or (pGlu-Gln)-CCK-8 $(25 \mathrm{nmol} / \mathrm{kg}$ body weight). Food intake, body weight, nonfasting plasma glucose, and insulin concentrations were monitored (1000 h) at intervals of 3-6 days. In addition, i.p. glucose tolerance $(18 \mathrm{mmol} / \mathrm{kg}$ body weight $)$ and insulin sensitivity (10 IU/kg body weight) tests were performed on day 28 in nonfasted mice. Mice fasted for $18 \mathrm{~h}$ were used to examine the metabolic response to 15 -min feeding. All acute tests commenced at $1000 \mathrm{~h}$. Pancreatic, liver, gastrocnemius muscle, and subcutaneous adipose tissues were excised at the end of the treatment period and processed for measurement of triacylglycerol content (Montgomery et al. 2010). Blood triacylglycerol and cholesterol content was also assessed at the end of the study. All animal experiments were carried out in accordance with the UK Animals (Scientific Procedures) Act 1986 and no mortalities were noted during the study.

\section{Biochemical analysis}

All blood samples were taken from the cut tip of the tail vein of conscious mice at the times indicated in the figures and immediately centrifuged using a Beckman microcentrifuge (Beckman Instruments, Galway, Ireland) for $30 \mathrm{~s}$ at $13000 \mathrm{~g}$. The resulting plasma was then aliquoted

Published by Bioscientifica Ltd 
into fresh Eppendorf tubes and stored at $-20^{\circ} \mathrm{C}$ before glucose, insulin, and triglyceride determinations. Glucose was assayed by an automated glucose oxidase procedure using a Beckman Glucose Analyzer II (Beckman Instruments). Insulin was determined by a modified dextrancoated charcoal RIA (Flatt \& Bailey 1981). Plasma and tissue lipid levels were measured as described previously (Montgomery et al. 2010).

\section{Statistical analysis}

Results are expressed as mean \pm s.E.M. Data were compared using ANOVA, followed by a Student-Newman-Keuls post hoc test. Area under the curve (AUC) analyses were calculated using the trapezoidal rule with baseline subtraction. $P<0.05$ was considered to be statistically significant.

\section{Results}

Effects of (pGlu-Gln)-CCK-8 on food intake, body weight, nonfasting plasma glucose, and insulin concentrations

Administration of (pGlu-Gln)-CCK-8 twice daily for 28 days resulted in significantly $(P<0.05-<0.01)$ reduced accumulated food intake from day 12 onward associated with decreased $(P<0.05)$ body weight on days 24 and 28
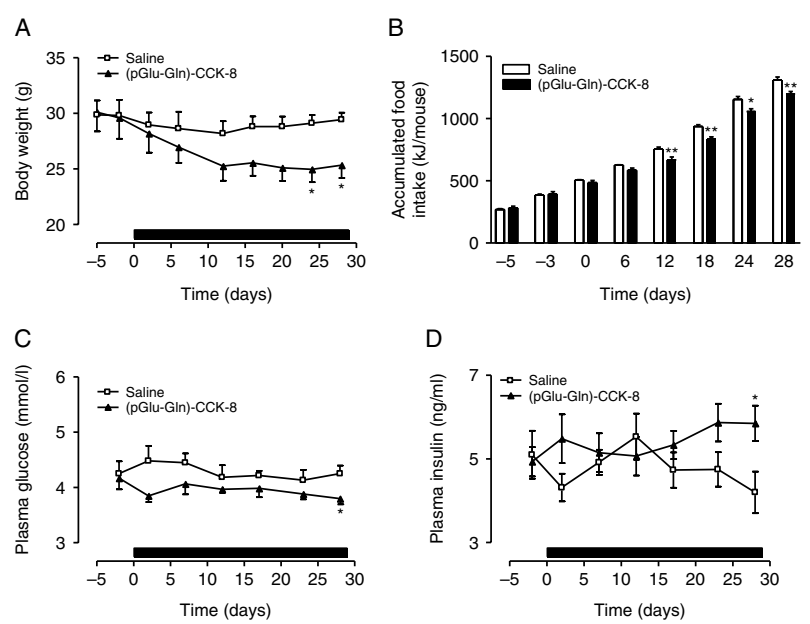

\section{Figure 1}

Effects of twice-daily (pGlu-GIn)-CCK-8 administration on (A) body weight, (B) accumulated food intake, (C) nonfasting plasma glucose, and (D) insulin. ( $A, B, C$ and D) Parameters were measured for 5 days before and 28 days during (indicated by horizontal black bar) treatment with saline or (pGlu-GIn)-CCK-8 ( $25 \mathrm{nmol} / \mathrm{kg}$ body weight). Values are mean \pm s.E.M. for eight mice. ${ }^{*} P<0.05$ and $* * P<0.01$ compared with saline group. when compared with saline-treated controls (Fig. 1A and $\mathrm{B})$. A significant decrease $(P<0.05)$ in plasma glucose and increase $(P<0.05)$ in plasma insulin concentrations were observed on day 28 of the study (Fig. 1C and D).

\section{Effects of (pGlu-GIn)-CCK-8 on glucose tolerance, metabolic response to feeding, and insulin sensitivity}

As shown in Fig. 2, (pGlu-Gln)-CCK-8 administration twice-daily for 28 days had no significant effect on plasma glucose levels or glucose-stimulated insulin concentrations following administration of an exogenous i.p. glucose load (Fig. 2). However, plasma glucose responses to $15 \mathrm{~min}$ feeding were significantly lowered $(P<0.05)$ at $105 \mathrm{~min}$ in (pGlu-Gln)-CCK-8-treated mice (Fig. 3A). Similarly, AUC glucose values were significantly $(P<0.05)$ decreased by (pGlu-Gln)-CCK-8 compared with controls $(71.5 \pm 23.2$ vs $332.3 \pm 90.3 \mathrm{mmol} / 1$ per min respectively; data not shown), despite similar food intakes of $0.3 \pm 0.1$ vs $0.4 \pm 0.1 \mathrm{~g} /$ mouse per $15 \mathrm{~min}$ respectively. Oral nutrient-stimulated insulin concentrations were not significantly altered between groups (Fig. 3B). However, the hypoglycemic action of insulin was significantly augmented in terms of post-injection $(P<0.05-<0.01)$ and AUC $(P<0.01)$ values in mice treated twice daily with (pGlu-Gln)-CCK-8 for 28 days (Fig. 4).

\section{Effects of (pGlu-GIn)-CCK-8 blood lipid content and triacylglycerol accumulation in muscle, liver, pancreatic, and adipose tissues}

Circulating cholesterol and triacylglycerol concentrations were similar in the control and (pGlu-Gln)-CCK-8 mice after 28 days of treatment (Fig. 5A and B). Similarly, there were no significant differences in the triacylglycerol content of muscle, pancreatic, and adipose tissue in (pGlu-Gln)CCK-8 mice (Fig. 5C, D, and E). However, (pGlu-Gln)-CCK-8 treatment twice daily for 28 days resulted in significantly $(P<0.01)$ reduced triacylglycerol accumulation in liver tissue when compared with controls (Fig. 5F).

\section{Discussion}

Genetic knockout studies have shown that annulment of $\mathrm{CCK}_{1}$ receptor activation in rats resulted in significant hyperphagia and mild obesity associated with hyperglycemia and impaired glucose tolerance (Moran 2008). However, similar gene knockout in mice was without effect on body weight and food intake regulation (Chen et al. 2007). In addition, while pair-feeding is known to

Published by Bioscientifica Ltd 
A

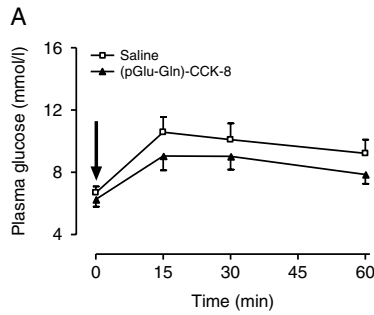

B

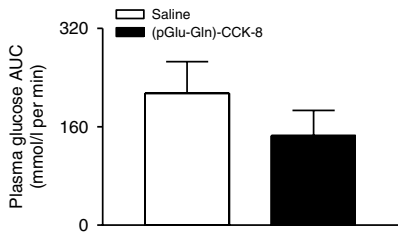

$\mathrm{C}$
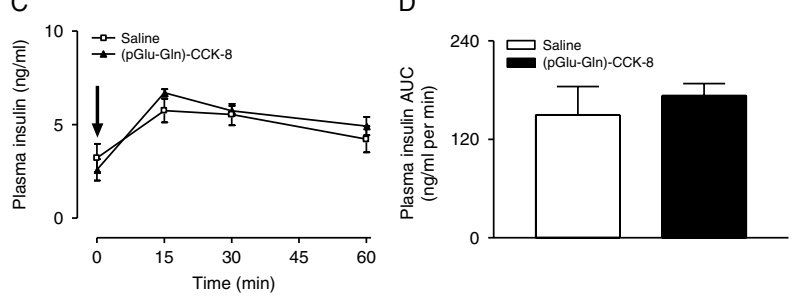

not to be associated with changes in energy expenditure (Irwin et al. 2012), highlighting the plasticity of signaling pathways involved in energy intake and weight regulation and suggesting multiple actions of (pGlu-Gln)-CCK-8. In addition, (pGlu-Gln)-CCK-8 was shown to stimulate insulin secretion from clonal $\beta$-cells and acutely improve glucose homeostasis in mice. However, when comparing the acute insulinotropic actions of (pGlu-Gln)-CCK-8 in vitro and in vivo, it would suggest that larger doses would be required to induce any prominent insulin-releasing effect during the current treatment regimen (Irwin et al. 2012). In agreement, circulating glucose and insulin were almost identical to saline-treated control mice, indicating lack of detrimental metabolic effects despite significantly lowered body weights. These observations accord with other studies using longer-acting CCK agonists, where the

Figure 2

Effects of twice-daily (pGlu-GIn)-CCK-8 administration on glucose tolerance and plasma insulin response to glucose. Tests were conducted after twicedaily treatment with saline or (pGlu-GIn)-CCK-8 ( $25 \mathrm{nmol} / \mathrm{kg}$ body weight) for 28 days. ( $A$ and $C$ ) Glucose ( $18 \mathrm{mmol} / \mathrm{kg}$ body weight) was administered at the time indicated by the arrow in nonfasted mice. (B and D) Plasma glucose and insulin AUC values for 0-60 min post-injection are also shown. Values are mean \pm s.E.M. for eight mice.

fully normalize energy control and metabolic responses in OLEFT rats (Bi et al. 2007), the beneficial effects of (pGlu-Gln)-CCK-8 are not reproduced by simple dietary restriction (Irwin et al. 2012). In the current study, we have used twice-daily administration of (pGlu-Gln)-CCK-8 to examine the overall metabolic effects under normal physiological conditions. This approach avoids the problems of lifelong compensatory actions.

Our previous in vitro and in vivo studies in high-fat and $o b / o b$ mice have demonstrated that (pGlu-Gln)-CCK-8 is a potent, longer-acting agonist of the $\mathrm{CCK}_{1}$ receptor (Irwin et al. 2012). In this study, twice-daily injection of normal mice with (pGlu-Gln)-CCK-8 for 28 days had no obvious adverse or toxic effects. Indeed, previous studies in our laboratory using (pGlu-Gln)-CCK-8 have established its safety in terms of lack of induction of pancreatic inflammation or development of anxiety (Irwin et al. 2012). Moreover, knockout rather than upregulation of the $\mathrm{CCK}_{1}$ receptor has been shown to predispose to anxiety-like behavior in rats (Schroeder \& Weller 2010). Body weights of (pGlu-Gln)-CCK-8-treated mice were substantially lower than controls by day 28 accompanied by predictable inhibitory effects on food intake, highlighting the therapeutic potential of (pGlu-Gln)-CCK-8 for obesity-diabetes (Verbaeys et al. 2007, Irwin et al. 2012). Interestingly, effects of the peptide were recently shown
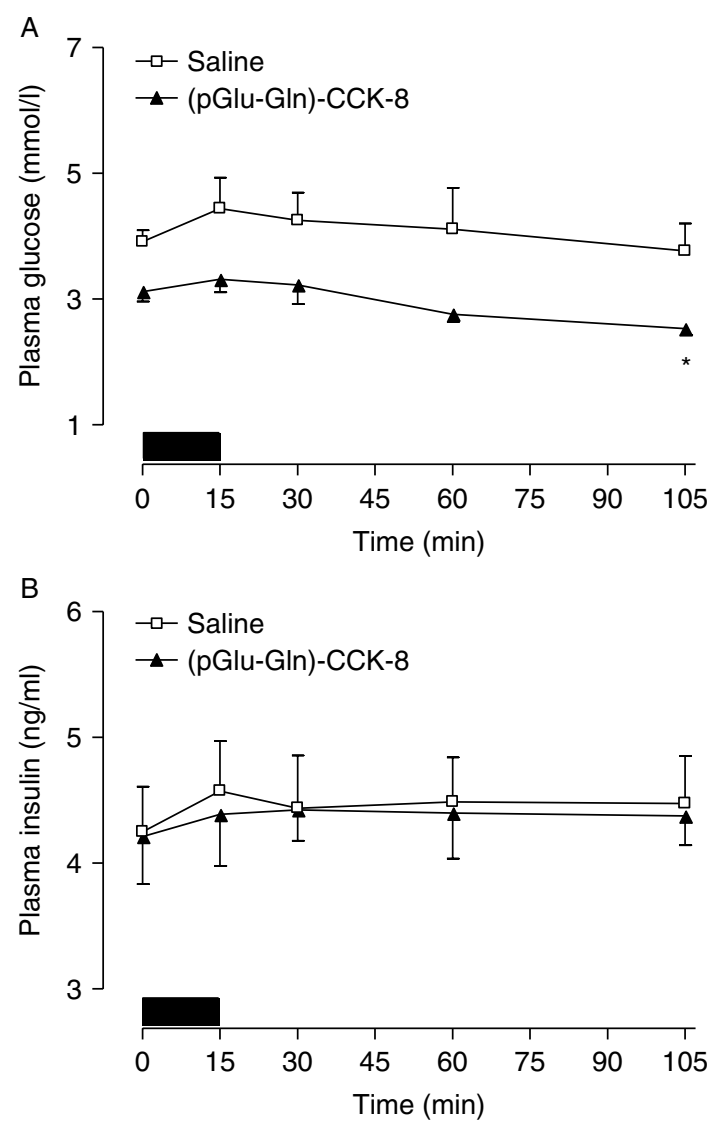

Figure 3

Effects of twice-daily (pGlu-GIn)-CCK-8 administration on (A) glucose and (B) insulin responses to feeding. Tests were conducted after twice-daily treatment with saline or ( $\mathrm{pGlu}-\mathrm{Gln})-\mathrm{CCK}-8$ ( $25 \mathrm{nmol} / \mathrm{kg}$ body weight) for 28 days. Mice were fasted for $18 \mathrm{~h}$ and allowed to refeed for $15 \mathrm{~min}$ (black horizontal bar indicates time of feeding). Values are mean \pm s.E.M. for eight mice. ${ }^{\star} P<0.05$ compared with saline group. 
A

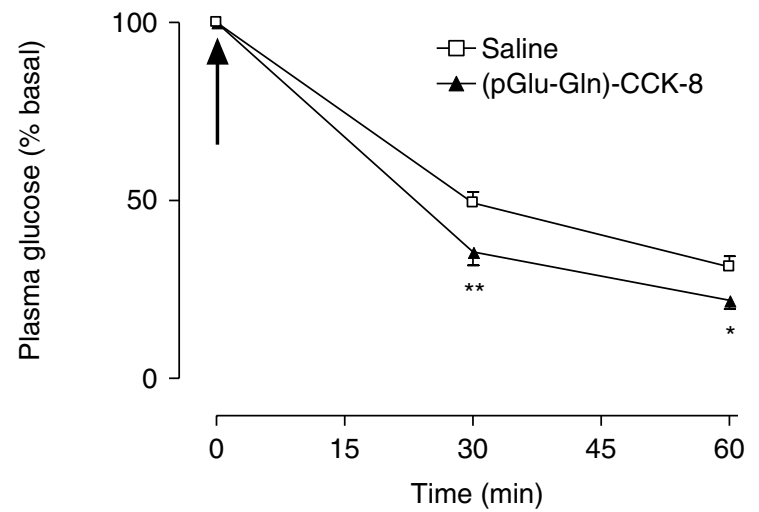

B

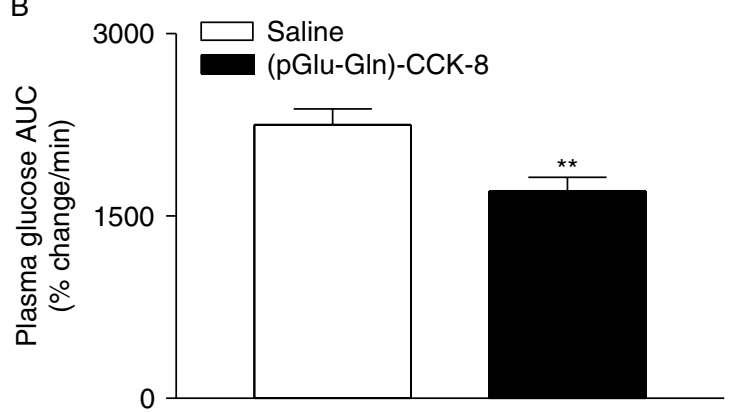

improvement of metabolic status in high-fat-fed and obese diabetic $(o b / o b)$ mice, including substantially decreased energy intake and body weight, improved glucose tolerance and insulin sensitivity, and significantly reduced triacylglycerol content of peripheral tissues (Irwin et al. 2012). Moreover, triacylglycerol accumulation in liver was also decreased in this study suggestive of improved peripheral insulin action. In keeping with this, when challenged with a test meal, glucose concentrations were lowered compared with those of saline-treated controls, despite similar nutrient-induced insulin levels. Interestingly, i.p. glucose tolerance was not affected by twice-daily (pGlu-Gln)-CCK-8 administration for 28 days, confirming normal glucose uptake and disposal mechanisms in these animals. In relation to these observations, it has been shown that CCK and incretin hormones may have complementary metabolic effects (Hisadome et al. 2011). This could account for the disparity between oral and i.p. nutrient challenge in the current setting. In agreement, there appears to be significant overlap in the hormonal expression of intestinal cells that secrete incretin hormones and CCK (Habib et al. 2012). In addition, assessment of the
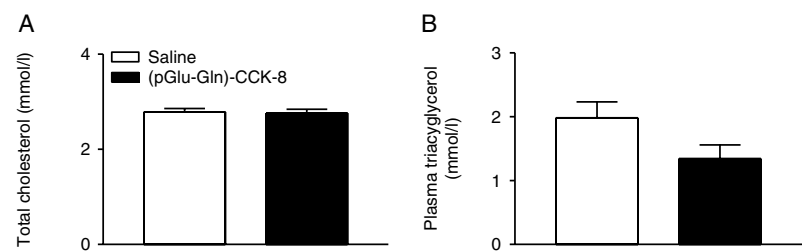

C
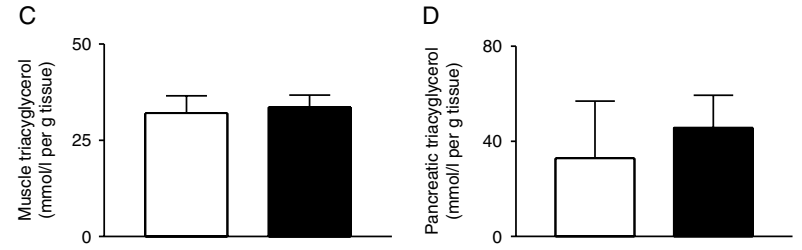

$E$

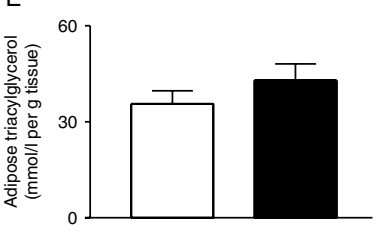

$\mathrm{F}$

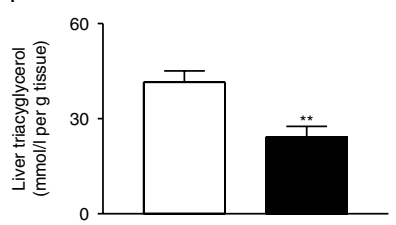
insulin sensitivity (Lo et al. 2011), mice receiving twicedaily (pGlu-Gln)-CCK-8 injections displayed marked augmentation of the glucose-lowering action of insulin by day 28. This is in harmony with the observed beneficial effects of (pGlu-Gln)-CCK-8 in animal models of obesity-diabetes (Irwin et al. 2012). Thus, twice-daily (pGlu-Gln)-CCK-8 administration results in marked

\section{Figure 5}

Effects of twice-daily (pGlu-GIn)-CCK-8 administration on (A and B) plasma cholesterol and triacylglycerol levels and (C, D, E and F) triacylglycerol content of muscle, pancreas, adipose, and liver tissue. Parameters were measured after 28 days of treatment with saline or (pGlu-GIn)-CCK-8 ( $25 \mathrm{nmol} / \mathrm{kg}$ body weight). Values are mean \pm S.E.M. for eight mice. $\star * P<0.01$ compared with saline group. 
expression of $\mathrm{CCK}_{1}$ and $\mathrm{CCK}_{2}$ receptors following prolonged treatment with (pGlu-Gln)-CCK-8 may have aided with interpretation of the current data set.

A key observation from this study was the lack of discernible harmful effects following sustained administration of (pGlu-Gln)-CCK-8. Indeed, due to scarcity of specific assays, knowledge about CCK in disease is currently limited (Rehfeld et al. 2007), highlighting the importance of our findings. Thus, circulating triacylglycerol and cholesterol levels were identical to lean controls in (pGlu-Gln)-CCK-8-treated mice, despite the well-characterized actions of CCK on gallbladder function and bile production (Rehfeld 2011). Moreover, $\mathrm{CCK}_{1}$ receptor activation has been shown to decrease the risk of gallstone formation in mice (Sato et al. 2003) and to attenuate inflammation in rats (Lubbers et al. 2010). In addition, this study highlights the lack of effect of sustained (pGlu-Gln)-CCK-8 treatment in normal mice on circulating glucose and insulin, glucose tolerance, and tissue and plasma triacylglycerol content. Moreover, previous studies with (pGlu-Gln)-CCK-8 have confirmed its safety in terms of lack of induction of pancreatic inflammation, development of anxiety, and preservation of islet structure (Irwin et al. 2012). Thus, the recent significant focus on peptide therapies, which has been based on the classical glucoregulatory incretin hormones, should be revisited (Holst et al. 2009), especially as meals consist of a mixture of components and nutrients that release a number of other gut-derived hormones that undoubtedly have potential therapeutic implications (Irwin et al. 2012). In effect, it appears highly likely that the beneficial effects of upregulation of $\mathrm{CCK}_{1}$ receptor action extend beyond direct effects on energy balance and encompass numerous other actions including effects on glucose homeostasis (Ahrén et al. 1991, Lavine et al. 2010).

In conclusion, this study has demonstrated that twicedaily administration of (pGlu-Gln)-CCK-8 results in beneficial metabolic effects in normal mice. Observation of decreased body weight gain and an enhancement in insulin sensitivity, without change of nutrient-induced pancreatic $\beta$-cell function, demonstrates important metabolic actions that are transferred to models of obesitydiabetes (Irwin et al. 2012). Overall, (pGlu-Gln)-CCK-8 appears to be an effective means of improving metabolic control, which could be particularly valuable in situations of obesity and insulin resistance.

\section{Declaration of interest}

N I, F P M O, and P R F hold shares with Diabetica Ltd., which has patents for exploitation of peptide therapeutics.

\section{Funding}

These studies were supported by the SAAD Trading and Contracting Company and the Department of Education and Learning, Northern Ireland.

\section{References}

Ahrén B, Pettersson M, Uvnäs-Moberg K, Gutniak M \& Efendic S 1991 Effects of cholecystokinin (CCK)-8, CCK-33, and gastric inhibitory polypeptide (GIP) on basal and meal-stimulated pancreatic hormone secretion in man. Diabetes Research and Clinical Practice 13 153-161. (doi:10.1016/0168-8227(91)90059-M)

Ali S, Lamont BJ, Charron MJ \& Drucker DJ 2011 Dual elimination of the glucagon and GLP-1 receptors in mice reveals plasticity in the incretin axis. Journal of Clinical Investigation 121 1917-1929. (doi:10.1172/ JCI43615)

Bi S, Chen J, Behles RR, Hyun J, Kopin AS \& Moran TH 2007 Differential body weight and feeding responses to high-fat diets in rats and mice lacking cholecystokinin 1 receptors. American Journal of Physiology. Regulatory, Integrative and Comparative Physiology 293 R55-R63. (doi:10.1152/ajpregu.00002.2007)

Chen S, Turner S, Tsang E, Stark J, Turner H, Mahsut A, Keifer K, Goldfinger M \& Hellerstein MK 2007 Measurement of pancreatic islet cell proliferation by heavy water labeling. American Journal of Physiology. Endocrinology and Metabolism 293 E1459-E1464. (doi:10.1152/ajpendo. 00375.2007)

Degen L, Matzinger D, Drewe J \& Beglinger C 2001 The effect of cholecystokinin in controlling appetite and food intake in humans. Peptides 22 1265-1269. (doi:10.1016/S0196-9781(01)00450-8)

Devlin MJ, Walsh BT, Guss JL, Kissileff HR, Liddle RA \& Petkova E 1997 Postprandial cholecystokinin release and gastric emptying in patients with bulimia nervosa. American Journal of Clinical Nutrition 65 114-120.

Flatt PR \& Bailey CJ 1981 Abnormal plasma glucose and insulin responses in heterozygous lean (ob/+) mice. Diabetologia 20 573-577. (doi:10.1007/BF00252768)

Gibbs J, Young RC \& Smith GP 1973 Cholecystokinin elicits satiety in rats with open gastric fistulas. Nature 245 323-325. (doi:10.1038/245323a0)

Habib AM, Richards P, Cairns LS, Rogers GJ, Bannon CA, Parker HE, Morley TC, Yeo GS, Reimann F \& Gribble FM 2012 Overlap of endocrine hormone expression in the mouse intestine revealed by transcriptional profiling and flow cytometry. Endocrinology 153 3054-3065. (doi:10.1210/en.2011-2170)

Hisadome K, Reimann F, Gribble FM \& Trapp S 2011 CCK stimulation of GLP-1 neurons involves $\{\alpha\} 1$-adrenoceptor-mediated increase in glutamatergic synaptic inputs. Diabetes 60 2701-2709. (doi:10.2337/ db11-0489)

Holst JJ, Vilsbøll T \& Deacon CF 2009 The incretin system and its role in type 2 diabetes mellitus. Molecular and Cellular Endocrinology 297 127-136. (doi:10.1016/j.mce.2008.08.012)

Irwin N, Frizelle P, Montgomery IA, Moffett RC, O'Harte FPM \& Flatt PR 2012 Beneficial effects of the novel cholecystokinin agonist (pGlu-Gln)-CCK-8 in animal models of obesity-diabetes. Diabetologia 55 2247-2258. (doi:10.1007/s00125-012-2654-6)

Kerr BD, Irwin N, O'Harte FP, Bailey CJ, Flatt PR \& Gault VA 2009 Fatty acid derivatised analogs of glucose-dependent tropic polypeptide with improved antihyperglycaemic and tropic properties. Biochemical Pharmacology 78 1008-1016. (doi:10.1016/j.bcp. 2009.05.037)

Kuntz E, Pinget M \& Damgé P 2004 Cholecystokinin octapeptide: a potential growth factor for pancreatic $\beta$ cells in diabetic rats. Journal of the Pancreas 5 464-475.

Lavine JA, Raess PW, Stapleton DS, Rabaglia ME, Suhonen JI, Schueler KL, Koltes JE, Dawson JA, Yandell BS, Samuelson LC et al. 2010 Cholecystokinin is up-regulated in obese mouse islets and expands 
$\beta$-cell mass by increasing $\beta$-cell survival. Endocrinology 151 3577-3588. (doi:10.1210/en.2010-0233)

Liddle RA 1994 Cholecystokinin. In Gut Peptides. Biochemistry and Physiology, pp 175-216. Eds JH Walsh \& GJ Dockray. New York: Raven.

Lo CM, Obici S, Dong HH, Haas M, Lou D, Kim DH, Liu M, D'Alessio D, Woods SC \& Tso P 2011 Impaired insulin secretion and enhanced insulin sensitivity in cholecystokinin-deficient mice. Diabetes $\mathbf{6 0}$ 2000-2007. (doi:10.2337/db10-0789)

Lubbers T, de Haan JJ, Luyer MD, Verbaeys I, Hadfoune M, Dejong CH, Buurman WA \& Greve JW 2010 Cholecystokinin/cholecystokinin-1 receptor-mediated peripheral activation of the afferent vagus by enteral nutrients attenuates inflammation in rats. Annals of Surgery $\mathbf{2 5 2}$ 376-382. (doi:10.1097/SLA.0b013e3181dae411)

Montgomery IA, Irwin N \& Flatt PR 2010 Active immunization against $\left(\mathrm{Pro}^{3}\right)$ GIP improves metabolic status in high-fat-fed mice. Diabetes, Obesity \& Metabolism 12 744-751. (doi:10.1111/j.1463-1326.2010. 01228.x)

Moran TH 2008 Unraveling the obesity of OLETF rats. Physiology \& Behavior 94 71-78. (doi:10.1016/j.physbeh.2007.11.035)

Moran TH, Ameglio PJ, Peyton HJ, Schwartz GJ \& McHugh PR 1993 Blockade of type A, but not type B, CCK receptors postpones satiety in rhesus monkeys. American Journal of Physiology 265 R620-R624.

Mutt V 1980. Cholecystokinin: isolation, structure and function. In Gastrointestinal Hormones, pp 169-221. Ed GBJ Glass. New York: Raven.

Mutt V \& Jorpes JE 1968 Structure of porcine cholecystokinin pancreozymin I. Cleavage with thrombin and with trypsin. European Journal of Biochemistry 6 156-162. (doi:10.1111/j.1432-1033.1968.tb00433.x)

O'Harte FP, Mooney MH, Kelly CM \& Flatt PR 1998 Glycated cholecystokinin-8 has an enhanced satiating activity and is protected against enzymatic degradation. Diabetes 47 1619-1624. (doi:10.2337/ diabetes.47.10.1619)

Rehfeld JF 2011 Incretin physiology beyond glucagon-like peptide 1 and glucose-dependent insulinotropic polypeptide: cholecystokinin and gastrin peptides. Acta Physiologica 201 405-411. (doi:10.1111/j.17481716.2010.02235.x)

Rehfeld JF, Friis-Hansen L, Goetze JP \& Hansen TV 2007 The biology of cholecystokinin and gastrin peptides. Current Topics in Medicinal Chemistry 7 1154-1165. (doi:10.2174/156802607780960483)

Sato N, Miyasaka K, Suzuki S, Kanai S, Ohta M, Kawanami T, Yoshida Y, Takiguchi S, Noda T, Takata Y et al. 2003 Lack of cholecystokinin-A receptor enhanced gallstone formation: a study in CCK-A receptor gene knockout mice. Digestive Diseases and Sciences 48 1944-1947. (doi:10.1023/A:1026110002713)

Schroeder M \& Weller A 2010 Anxiety-like behavior and locomotion in CCK1 knockout rats as a function of strain, sex and early maternal environment. Behavioural Brain Research 211 198-207. (doi:10.1016/ j.bbr.2010.03.038)

Strader AD \& Woods SC 2005 Gastrointestinal hormones and food intake. Gastroenterology 128 175-191. (doi:10.1053/j.gastro.2004.10.043)

Verbaeys I, León-Tamariz F, Buyse J, De Cuyper M, Pottel H, Van Boven M \& Cokelaere M 2007 PEGylated cholecystokinin prolongs satiation in rats: dose dependency and receptor involvement. British Journal of Pharmacology 152 396-403. (doi:10.1038/sj.bjp.0707390)

Verbaeys I, León-Tamariz F, Pottel H, Decuypere E, Swennen Q \& Cokelaere M 2008 PEGylated cholecystokinin is more potent in inducing anorexia than conditioned taste aversion in rats. British Journal of Pharmacology 155 417-423. (doi:10.1038/bjp.2008.257)

Verbaeys I, León-Tamariz F, Buyse J, Decuypere E, Pottel H \& Cokelaere M $2009 a$ Lack of tolerance development with long-term administration of PEGylated cholecystokinin. Peptides 30 699-704. (doi:10.1016/j. peptides.2008.11.010)

Verbaeys I, León-Tamariz F, De Buyser K, Buyse J, Decuypere E, Pottel H \& Cokelaere M 2009b Dose-response effects of PEGylated cholecystokinin on the behavioral satiety sequence. Physiology \& Behavior 98 198-204. (doi:10.1016/j.physbeh.2009.05.010)

Received in final form 10 September 2012

Accepted 10 October 2012

Accepted Preprint published online 10 October 2012
○ 2013 Society for Endocrinology Printed in Great Britain
Published by Bioscientifica Ltd. 